\title{
PENGARUH PERKEMBANGAN KARIER DAN KEPUASAN KERJA TERHADAP KOMITMEN ORGANISASI
}

\author{
Resia Priskila dan Mei Ie \\ Fakultas Ekonomi Universitas Tarumanagara Jakarta \\ Email: resia.115170129@stu.untar.ac.id,meii@fe.untar.ac.id
}

\begin{abstract}
Senior High School (SMA) institution is an educational institution that is required to bring out graduates so they can join public universities (PTN) and become prime human resources. So school educational institutions need human resources such as school principals and teachers as organizational wheels to drive activities. To achieve these goals, the school is required to pay attention to the work commitment of the teachers by paying attention to career development variables and job satisfaction, this is based on career development that runs in an organization that can increase their commitment to the organization in achieving organizational goals because the teachers have job satisfaction with the existing job promotion system so as to improve work quality. The purpose of this study was to determine the effect of career development and job satisfaction on organizational commitment in a highschool in Jakarta teachers. Researchers distributed questionnaires to all teachers who teach at a highschool in Jakarta, totaling 55 respondents to be the sample for the entire study. The data analysis method in this research is quantitative method using Structural Equation Modeling (SEM), through the Partial Least Square approach. The results of this study show that career development affects organizational commitment to teachers of a highschool in Jakarta and job satisfaction affects organizational commitment of a highschool in Jakarta teachers.
\end{abstract}

Keywords: Career Development, Job Satisfaction, Organizational Commitment.

Abstrak: Lembaga institusi Sekolah Menengah Atas (SMA) merupakan lembaga pendidikan yang dituntut untuk menghasilkan lulusan yang unggul agar dapat masuk PTN dan menjadi sumber daya manusia yang unggul. Oleh karena itu, institusi lembaga pendidikan sekolah memerlukan sumber daya manusia sebagai penggerak roda kegiatan seperti kepala sekolah dan guru dalam roda organisasi. Dalam mencapai tujuan tersebut pihak sekolah dituntut untuk memperhatikan komitmen kerja bapak/ibu guru dengan memperhatikan variabel pengembangan karir dan kepuasan kerja. Hal tersebut didasarkan atas pengembangan karir yang berjalan dalam sebuah organisasi dapat meningkatkan komitmen mereka terhadap organisasi dalam mencapai tujuan organisasi karena karyawan bapak/ibu guru memiliki kepuasan kerja dengan adanya sistem promosi jabatan yang ada sehingga meningkatkan kualitas kerja. Tujuan penelitian ini adalah untuk mengetahui pengaruh pengembangan karir dan kepuasan kerja terhadap komitmen organisasi pada Guru di sebuah SMA di Jakarta. Peneliti menyebarkan kuesioner kepada seluruh bapak/ibu guru yang mengajar di sebuah SMA di Jakarta yang berjumlah 55 responden. Metode analisa data dalam penelitian ini yaitu metode kuantitatif dengan menggunakan Structural Equation Modeling (SEM), melalui pendekatan Partial Least Square, Hasil penelitian ini menunjukkan pengembangan karir berpengaruh terhadap komitmen organisasi pada guru di sebuah SMA di Jakarta dan kepuasan kerja berpengaruh terhadap komitmen organisasi pada guru di sebuah SMA di Jakarta.

Kata Kunci : Kepuasan Kerja, Komitmen Organisasi, Pengembangan Karir. 


\section{LATAR BELAKANG}

Dalam menyongsong target pendidikan 4.0, maka bangsa Indonesia dituntut untuk mempersiapkan sumber daya manusia secara maksimal untuk memperoleh kualitas lulusan yang mampu bersaing. Kualitas lulusan tersebut dalam institusi lembaga pendidikan sekolah bergantung pada sumber daya manusia yang menjadi penggerak roda kegiatan seperti kepala sekolah, guru, dan karyawan sekolah yang berkualitas sebagai penggerak kegiatan organisasi. Maka upaya yang dilakukan pemerintah dengan meningkatkan kualitas pendidikan dan kualitas pendidik dengan upaya menumbuhkan komitmen organisasi bapak/ibu guru terhadap sekolahnya. Dengan rasa cinta terhadap organisasinya dalam hal ini lembaga pendidikan sekolah maka bapak ibu guru akan memberikan kemampuan terbaik mereka bagi lembaga pendidikan mereka bekerja, namun komitmen organisasi tidak muncul begitu saja melainkan dari kepuasan kerja yang dibangun sebagaimana yang dijelaskan penelitian Al-Shawabkeh (2017). Hal tersebut menjelaskan kekuatan komitmen yang dimiliki oleh karyawan dapat mengurangi niat karyawan untuk meninggalkan perusahaan. Serta institusi lembaga pendidikan hendakanya menawarkan program pengembangan karier yang menarik sehingga mendorong bapak / ibu guru bekerja jauh lebih maksimal untuk mencapai target yang diharapkan.

Hal tersebut dibuktikan pada penelitian Saragih dan Suhendro (2020) dengan obyek penelitian bapak/ibu guru SMA Negeri I Dolok Batu Nanggar yang berjumlah 52 orang guru menggunakan metode kuantitatif regresi linear berganda menunjukkan kepuasan kerja guru berpengaruh positif dan signifikan terhadap komitmen guru akan tetapi dalam penelitian menggunakan variabel yang sama yang dilakukan Iskandar dan Surohadikusumo (2020) menunjukkan hasil sebaliknya hasil penelitian kepuasan kerja guru tidak berpengaruh terhadap komitmen organisasi pada Teladan Prima Group, sedangkan pengembangan karir terbukti menunjukkan hasil pengembangan karir mempengaruhi komitmen organisasi PT. Nusa Raya Cipta (Chandra dan Bahri, 2020).

Dari perbedaan hasil penelitian tersebut mendorong peneliti untuk melakukan pembuktian hasil penelitian terhadap variabel komitmen organisasi pada guru di sebuah SMA di Jakarta. Hal tersebut didasarkan pada fenomena guru di sebuah SMA di Jakarta dalam kurun waktu sepuluh tahun terakhir terjadi mutasi dalam peningkatan karir seperti Bpk. Dr. M. Husin guru Fisika menjadi Kepala Sekolah, Kasi Kurikulum, hingga menduduki Kepala Bidang SMA/SMP Dinas Pendidikan Provinsi DKI Jakarta, Ibu Rusmala Nainggolan M.Pd. Guru Matematika di promosikan menjadi Kepala Sekolah, Ibu Lina Dinawati M.Pd. guru bahasa Indonesia menjadi Wakil Kurikulum di SMA Negeri 29 Jakarta, Bpk. Agus Rahayu MM menjadi Wakil Kurikulum di SMA Negeri 18 Jakarta. Tujuan penelitian ini adalah untuk mengetahui pengaruh pengembangan karir terhadap komitmen organisasi pada Guru di sebuah SMA di Jakarta, dan mengetahui pengaruh kepuasan kerja terhadap komitmen organisasi pada Guru di sebuah SMA di Jakarta.

\section{LANDASAN TEORI}

Menurut Pritanadhira (2019), basis teori untuk menjelaskan hubungan antar variabel penelitian yaitu perspektif pertaruhan sisi atau pertukaran (the side-bets/exchange), dimana komitmen organisasi dalam pandangan the side bets (exchange) perspective menekankan keinginan pegawai untuk bertahan dalam suatu organisasi karena adanya transaksi antara individu dengan pegawai. Pegawai dalam suatu organisasi akan mempertimbangkan ada atau tidaknya keuntungan dan kerugian yang didapatkan jika tetap bertahan. 


\section{Komitmen Organisasi}

Menurut Priansa (2018) komitmen organisasi adalah loyalitas pegawai atau karyawan terhadap organisasi, yang tercermin dari keterlibatan yang tinggi untuk mencapai tujuan organisasi. Robbin and Judge (2018) menjelaskan komitmen organisasi merupakan kekuataan yang bersifat relatif dari individu dalam mengindentifikasi keterlibatan dirinya kedalam bagian organisasi yang dicirikan oleh penerimaan nilai dan tujuan organisasi, kesediaan berusaha demi organisasi dan keinginan mempertahankan keanggotaan dalam organisasi.

Dari pendapat-pendapat di atas dapat disimpulkan bahwa komitmen organisasi merupakan sikap yang dimiliki seseorang terhadap organisasinya dalam hal ini institusi atau organisasi untuk tetap berada dalam organisasi tersebut untuk membantu mencapai tujuan organisasi.

\section{Pengembangan Karir}

Menurut Siagian (2015) pengembangan karir adalah perubahan-perubahan pribadi yang dilakukan seseorang untuk mencapai suatu rencana karir. Widodo (2016) menjelaskan pengembangan karier adalah serangkaian aktivitas sepanjang hidup yang berkontribusi pada eksplorasi, pemantapan, keberhasilan dan pemenuhan karier seseorang. Lebih lanjut Mangkunegara (2013) menjelaskan pengembangan karir merupakan aktivitas kepegawaian yang membantu pegawai merencanakan karir masa depan mereka di perusahaan agar perusahaan dan pegawai yang bersangkutan dapat mengembangkan diri secara maksimum.

Berdasarkan beberapa definisi di atas dapat disimpulkan bahwa pengembangan karir adalah aktivitas yang membantu pegawai merencanakan masa depan karir mereka di perusahaan agar pegawai dan perusahaan dapat mengembangkan diri secara maksimum promosi ke jabatan-jabatan yang lebih baik dalam hierarki hubungan kerja selama kehidupan kerja seseorang.

\section{Kepuasan Kerja}

Kepuasan kerja menurut Hasibuan (2016) adalah suatu sikap bersifat emosional yaitu senang dan cinta terhadap pekerjaannya, dapat dilihat melalui etika kerja, ketertiban dan pencapaian pekerjaannya. Sementara kepuasan kerja didefinisikan oleh Robbins dan Judge (2018) sebagai kegiatan untuk mencapai suatu tujuan perusahaan dengan efektif dan efisien, keterlibatan pekerjaan memiliki peran penting, dimana orang menilai pekerjaan tersebut dianggap penting bagi harga diri mereka untuk mencapai tujuan yang ditetapkan oleh perusahaan. Menurut Priansa (2016) kepuasan kerja merupakan sekumpulan perasaan, keyakinan, dan pikiran tentang bagaimana respon terhadap pekerjaannya. Dari definisi kepuasan kerja di atas, dapat disimpulkan bahwa kepuasan kerja merupakan suatu sikap atau perasaan puas tidaknya yang ditunjukkan oleh karyawan dalam melaksanakan tugas yang diberikan oleh pemimpin.

Berdasarkan definisi variabel X dan Y diatas, Karia dan Assari (2018) menjelaskan karyawan yang berada berkomitmen tinggi untuk organisasi mereka berkontribusi lebih efektif untuk pertumbuhan perusahaan dan keberhasilan. Komitmen organisasi merupakan unsur yang paling penting dalam menentukan keberhasilan atau kegagalan suatu perusahaan. Penelitian yang dilakukan oleh Karia dan Assari (2018), menunjukkan bahwa karyawan yang berada berkomitmen tinggi untuk organisasi mereka berkontribusi lebih efektif untuk pertumbuhan perusahaan dan keberhasilan. Meningkatkan komitmen organisasi menjadi salah satu tantangan yang besar dalam organisasi untuk menumbuhkan loyalitas pegawai dalam penelitian ini bapak/ibu guru untuk memberikan kinerja terbaik bagi sekolah serta untuk mencapai target visi, misi dan tujuan sekolah.

Dalam mencapai tujuan tersebut pihak sekolah dituntut untuk memperhatikan dan memperbaiki variabel yang mempengaruhinya, yaitu pengembangan karir dan kepuasan kerja sebagaimana penelitian Marbun dan Kasmirudin (2017) yang menunjukkan pengembangan 
karir mempengaruhi komitmen organisasi begitu halnya dengan kepuasan kerja mempengaruhi organisasi. Hal tersebut didasarkan atas pengembangan karir yang berjalan dalam sebuah organisasi dapat meningkatkan komitmen mereka terhadap organisasi dalam mencapai tujuan organisasi karena karyawan dalam hal ini bapak/ibu guru memiliki kepuasan kerja dengan adanya sistem promosi jabatan yang ada sehingga meningkatkan kualitas kerja. Berdasarkan penulisan di atas, maka gambar kerangka teorinya sebagai berikut:

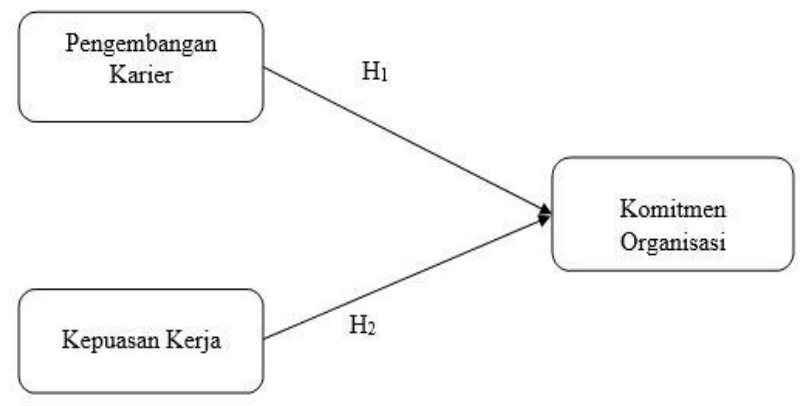

Gambar 1

Kerangka Pemikiran

Dari kerangka pemikiran gambar 1, maka hipotesis dalam penelitian ini adalah sebagai berikut:

$\mathrm{H}_{1}$ : Pengembangan karir memiliki pengaruh positif terhadap komitmen organisasi pada Guru di sebuah SMA di Jakarta.

$\mathrm{H}_{2}$ : Kepuasan kerja memiliki pengaruh positif terhadap komitmen organisasi pada Guru di sebuah SMA di Jakarta.

\section{METODOLOGI}

Desain penelitian menggunakan pendekatan kuantitatif dengan desain kausal untuk mengetahui pengaruh suatu variabel dengan variabel lain, dimana penelitian ini bertujuan untuk menguji hipotesis tentang pengaruh satu atau beberapa variabel terhadap variabel lainnya dengan menggunakan structure equation modeling (SEM) dengan bantuan program SmartPLS 3.2.8. Penelitian ini menyebarkan kuesioner kepada seluruh bapak/ibu guru yang mengajar di sebuah SMA di Jakarta yang berjumlah 55 responden untuk dijadikan sampel penelitian sehingga penelitian ini menjadikan seluruh populasi menjadi responden penelitian.

Berdasarkan data yang telah dikumpulkan, diketahui bahwa sebanyak 55 responden Bapak/Ibu guru di sebuah SMA di Jakarta dengan karakteristik data berdasarkan jenis kelamin responden menunjukkan 33 responden $(60 \%)$ berjenis kelamin perempuan, dan 22 responden $(40 \%)$ berjenis kelamin laki-laki, dari usia responden menunjukkan 11 responden $(20 \%)$ berusia $<25$ tahun, sebanyak 11 responden $(20 \%)$ berusia $26 \mathrm{~s} / \mathrm{d} 30$ tahun, sebanyak 8 responden $(14.5 \%)$ berusia $31 \mathrm{~s} / \mathrm{d} 40$ tahun, sebanyak 17 responden $(30 \%)$ berusia $41 \mathrm{~s} / \mathrm{d} 50$ tahun dan sebanyak 8 responden $(14.5 \%)$ berusia $>51$ tahun, untuk status menunjukkan 34 responden $(61.8 \%)$ berstatus PNS, sebanyak 21 responden $(38.2 \%)$ berstatus KKI, dan berdasarkan lama mengajar sebanyak 13 responden $(23.6 \%)$ lama mengajar $<5$ tahun, sebanyak 15 responden (27.3\%) lama mengajar 6 s/d 10 tahun, sebanyak 8 responden $(14.5 \%)$ lama mengajar $11 \mathrm{~s} / \mathrm{d} 15$ tahun, sebanyak 10 responden (18.2\%) lama mengajar $16 \mathrm{~s} / \mathrm{d} 20$ tahun dan sebanyak 9 responden $(16.4 \%)$ lama mengajar $>21$ tahun.

Di bagian objek penelitian terdapat pernyataan dan jawaban yang telah dijawab oleh responden. Pada variabel pengembangan karir dimensi yang berpengaruh besar yaitu informasi promosi pada pernyataan kuesioner kedelapan Kepala Sekolah memberikan informasi syarat promosi kenaikan jabatan secara transparan dengan persentase mayoritas jawaban $74.5 \%$ 
setuju. Sementara dimensi terendah dalam variabel pengembangan karir terdapat pada dimensi kepedulian atasan pada pernyataan keempat, Kepala Sekolah membantu saya dalam meningkatkan kemampuan manajerial sekolah dengan persentase mayoritas jawaban $54.5 \%$. Pada variabel kepuasan kerja dimensi yang berpengaruh besar yaitu supervision pada pernyataan kuesioner kedelapan kepala sekolah mempunyai motivasi kerja yang tinggi dalam mendorong saya mencapai target capaian kriteria nilai minimum siswa yang ditetapkan. dengan persentase mayoritas jawaban $58.2 \%$ setuju. Sementara dimensi terendah dalam variabel kepuasan kerja terdapat pada dimensi work it self pada pernyataan pertama, saya merasa senang dengan tingkat tanggung jawab dalam pekerjaan saya. dengan persentase mayoritas jawaban $45.5 \%$. Untuk variabel komitmen organisasi dimensi yang berpengaruh besar yaitu afective comitment pada pernyataan ketiga saya merasa senang menghabiskan sisa karir saya di organisasi ini dengan persentase mayoritas jawabannya $69.1 \%$ setuju. Sementara dimensi terendah dalam variabel komitmen organisasi terdapat pada dimensi continuance comitment pada pernyataan kelima, banyak hal dalam kehidupan saya yang terganggu jika saya memutuskan meninggalkan organisasi saya sekarang dengan persentase mayoritas jawabannya $56.4 \%$ setuju.

Penelitian ini menggunakan skala likert 1-5 untuk mengukur variabel dalam penelitian ini yaitu Kepuasan Kerja, Komitmen Organisasi, Perkembangan Karir dengan 1 menunjukkan

"sangat tidak setuju' dan 5 menunjukkan "sangat setuju." Instrumen dalam penelitian ini untuk menguji validitas dilakukan analisis Convergent validity dan discriminant validity dengan hasil analisis convergent valididy yaitu nilai loading factor harus lebih besar dari 0.7 . Apabila nilai loading factor sebesar 0,5-0,6 masih dapat dimaklumi. dan nilai AVE seluruh variabel lebih besar dari 0,5 (Hair et al, 2014).

Kemudian untuk analisis discriminant validity menunjukkan nilai cross loading tiap indikator variabelnya lebih besar dari korelasi antar variabel lainnya yang berada dalam satu baris dan analisis Fornell-Larcker menunjukkan nilai akar kuadrat AVE lebih besar dari korelasi antar variabel lainnya sehingga seluruh instrumen dinyatakan valid (Hair et al, 2014). Sementara untuk analisis reliabilitas didasarkan pada nilai composite reliability (DillonGoldstein's) yang masing-masing hasilnya menunjukkan nilai lebih dari 0,7 sehingga semua indikator dalam penelitian adalah reliabel (Hair et al, 2014). Sedangkan untuk mengevaluasi adanya hubungan yang dihipotesiskan dalam inner model. Kriteria yang diperlukan seperti: coefficient of determination $\left(R^{2}\right)$, cross-validated redundancy $\left(\mathrm{Q}_{2}\right)$, dan uji hipotesa. Pengumpulan data pada penelitian ini dilakukan dengan pembagian kuesioner secara online dengan menggunakan google-form dan analisis dengan menggunakan structure equation modeling (SEM) dengan bantuan program SmartPLS 3.2.8.

\section{HASIL UJI STATISTIK}

\section{Uji Validitas}

Uji validitas dilakukan dengan Convergent validity dan discriminant validity. Converent validity dalam penelitian ini menggunakan penilaian AVE dan loading factor. Menurut Hair et al (2014), uji validitas konvergen dikatakan valid apabila nilai AVE lebih besar dari 0,5 dan loading factor lebih besar dari 0,6. Uji validitas dan hasil akhirnya dapat dilihat pada Gambar 2. 


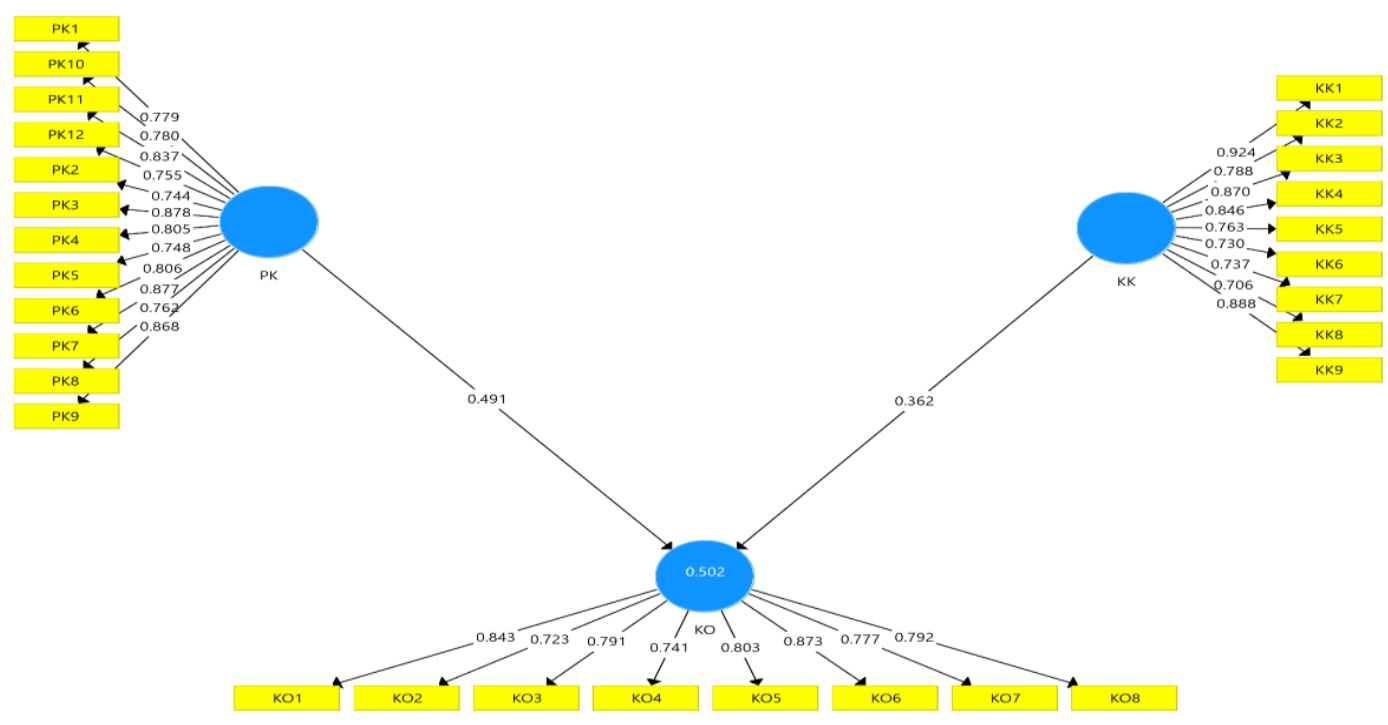

Gambar 2

Sumber: Olahan data dari SmartPLS 3

Hasil Analisis Validitas Konvergen

\section{Uji Reliabilitas}

Tabel 1.

Hasil Analisis Reliabilitas

\begin{tabular}{|l|r|}
\hline & \multicolumn{2}{|l|}{$\begin{array}{l}\text { Composite } \\
\text { Reliability }\end{array}$} \\
\hline PK & 0,956 \\
\hline KK & 0,944 \\
\hline KO & 0,932 \\
\hline
\end{tabular}

Sumber: Data primer yang diolah, 2020.

Menurut Arikunto (2013) hasil nilai cronbach's alpha di atas 0.6 dinyatakan reliabel. Maka dapat disimpulkan bahwa Composite Reliability masing-masing variabel memiliki nilai lebih besar dari 0,6. Sehingga disimpulkan bahwa variabel-variabel yang digunakan dalam penelitian ini dinyatakan reliabel.

\section{Hasil Uji Q2}

Pengukuran struktural adalah Q2 predictive relevance yang berfungsi untuk memvalidasi model. Pengukuran ini cocok jika variabel latin endogen memiliki model pengukuran reflektif. Hasil Q2 predictive relevance dikatakan baik jika nilainya > yang menunjukkan variabel laten eksogen baik (sesuai) sebagai variabel penjelas yang mampu memprediksi variabel endogennya. $\mathrm{Q}^{2}$ adalah sarana untuk menilai relevansi dari suatu data yang akan dianalisis.

Tabel 2.

Hasil Analisis $Q^{2}$

\begin{tabular}{|c|c|}
\hline Variabel & Q Square \\
\hline Komitmen Organisasi (Y) & 1.00 \\
\hline
\end{tabular}

Sumber: Olahan data dari SmartPLS 3 
Berdasarkan hasil $\mathrm{Q}^{2}$ di komitmen organisasi didapatkan hasil senilai 1.00. Dan dari hasil ini dibuktikan bahwa nilai tersebut relevan, karena hasil $\mathrm{Q}^{2}$ lebih besar dari 0 .

\section{Hasil Uji Koefisien Determinasi}

Menurut Hair et al (2014), dalam pengujian koefisien determinasi digunakan untuk melihat hasil uji pada $R$-Square yang menunjukkan besarnya kontribusi variabel independen terhadap variabel dependen serta mempunyai nilai yang berkisar diantara 0 sampai 1 , nilai pada koefisien determinasi dikelompokkan menjadi $0.75,0.5$ dan 0.25 yang dapat digunakan untuk menjelaskan pengaruh substansial, moderat dan lemah pada variabel laten.

Tabel 3.

Hasil Pengujian R-Square

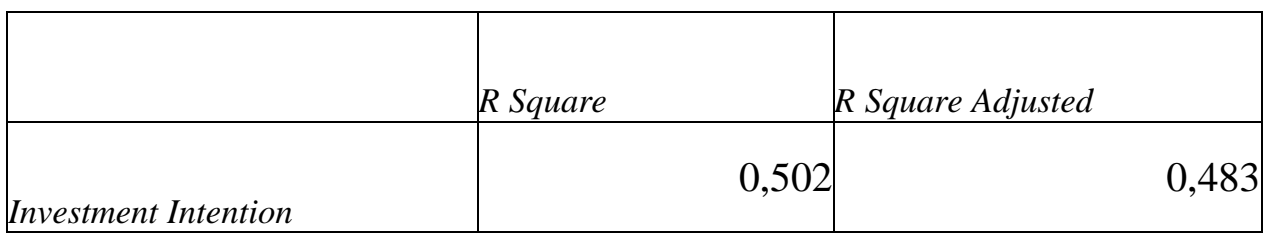

Sumber: Olahan data dari SmartPLS 3

Pada Tabel 3 menunjukkan bahwa nilai $R$-square variabel Investment Intention dapat dijelaskan sebesar 50,2 persen oleh variabel Personality Traits, Product Involvement dan Risk Avoidance sedangkan sisanya 49,8 persen dapat dijelaskan pada variabel-variabel lainnya diluar variabel pada penelitian ini. Nilai $R$-square pada penelitian ini dikategorikan moderat.

\section{Hasil Pengujian Hipotesis}

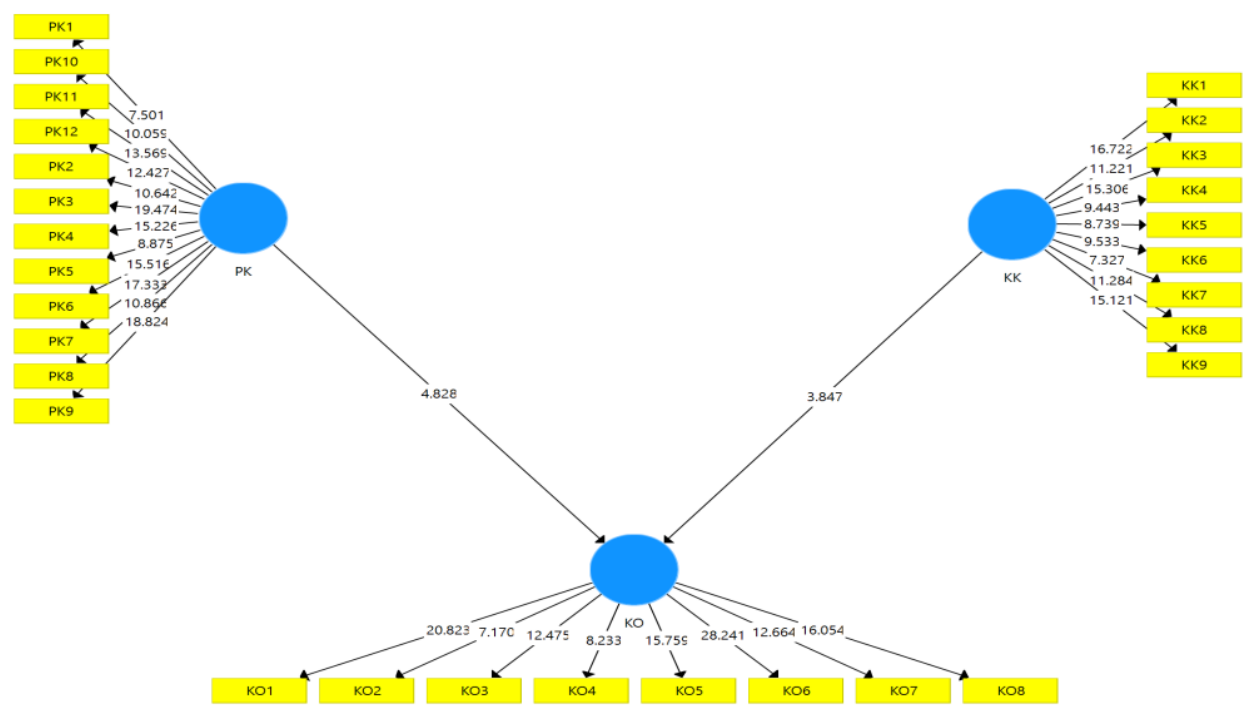

Gambar 3

Hasil Bootstrapping

Sumber: Olahan data dari SmartPLS 3 
Tabel 4.

Hasil Pengujian Hipotesis

\begin{tabular}{|l|c|c|}
\hline & T-Statistics & P Values \\
\hline Pengembangan Karir $\rightarrow$ Komitmen Organisasi & 3.847 & $\mathbf{0 . 0 0 0}$ \\
\hline Kepuasan Kerja $\longrightarrow$ Komitmen Organisasi & 4.828 & $\mathbf{0 . 0 0 0}$ \\
\hline
\end{tabular}

Sumber: Olahan data dari SmartPLS 3

Berdasarkan Tabel 4 dapat ditarik kesimpulan bahwa variabel pengembangan karir, dan kepuasan kerja memiliki pengaruh positif dan signifikan terhadap komitmen organisasi dengan tingkat keyakinan $95 \%(\propto=5 \%)$, dapat dilihat jika variabel pengembangan karir memiliki $t$ statistics sebesar 3.847 dan $p$ values sebesar 0.000. Dapat diartikan $t$-statistics yang melebihi 1,96 dan $p$ values kurang dari 5\% atau 0.05, maka dalam hipotesis 1 diterima. Dengan demikian pengembangan karir berpengaruh positif terhadap komitmen organisasi, sedangkan kepuasan kerja memiliki $t$-statistics yang sebesar 4.828 dan nilai $p$ values sebesar 0.000. Dapat diartikan jika nilai $t$-statistics lebih besar dari 1,96 dan nilai $p$ values yang tidak melebihi 5\%, maka hipotesis 2 dapat diterima. Dengan demikian kepuasan kerja berpengaruh positif terhadap komitmen organisasi.

\section{DISKUSI}

Dalam pembahasan ini, akan dibahas tentang hasil penelitian dari peneliti terhadap responden guru yang mengajar di sebuah SMA di Jakarta. Penelitian ini membahas beberapa variabel yang digunakan, yaitu variabel pengembangan karir, kepuasan kerja dan komitmen organisasi. Melalui uji statistik menggunakan software Smart PLS menunjukkan dalam hasil analisis $\mathrm{R}^{2}$ dari komitmen organisasi sebesar 0,502. Artinya 50,2\% variabel komitmen organisasi dapat dijelaskan oleh pengembangan karir dan kepuasan kerja serta sisanya $49.8 \%$ dijelaskan oleh variabel lain di luar penelitian ini serta hasil ini dibuktikan bahwa nilai tersebut relevan, karena hasil $\mathrm{Q}^{2}$ lebih besar dari 0 .

Pada path analysis, dengan bootstrapping menunjukkan jika variabel pengembangan karir terhadap komitmen organisasi menghasilkan nilai $t$-statistics sebesar 3.847 dan $p$ values sebesar 0.000 dan variabel kepuasan kerja terhadap komitmen organisasi menghasilkan $t$ statistics sebesar 4.828 dan $p$ values sebesar 0.000. Dapat disimpulkan bahwa hasil analisis ini semua variabel memiliki hasil yang positif, sehingga setiap variabel memiliki hubungan yang positif dan signifikan.

Hasil uji hipotesis pertama dapat diterima pengembangan karir berpengaruh positif terhadap komitmen organisasi. Hasil penelitian ini didukung oleh penelitian Marbun dan Kasmirudin (2017) dengan 48 responden karyawan Bagian Umum PT Perkebunan Nusantara V PEKANBARU yang menunjukkan bahwa pengembangan karir mempengaruhi komitmen organisasi. Penelitian Chandra dan Bahri (2020), menunjukkan bahwa pengembangan karir mempengaruhi komitmen organisasi dengan menggunakan metode analisis regresi linear berganda pada 60 karyawan PT Nusa Raya Cipta. Serta Yunus et al (2018), menunjukkan bahwasanya pengembangan karir berpengaruh positif dan signifikan terhadap komitmen organisasi, dimana penelitian ini mengambil sampel 82 pegawai PT Bank Mandiri Persero Tbk Cabang Makasar.

Penyediaan program pengembangan karier yang tepat mampu meningkatkan komitmen karyawan pada organisasi. Kekuatan komitmen yang dimiliki oleh karyawan dapat mengurangi niat karyawan untuk meninggalkan perusahaan. Organisasi yang tidak menawarkan program 
pengembangan karier yang menarik dapat kehilangan karyawan yang baik karena pesaing menawarkan peluang kerja yang lebih baik

Hasil uji hipotesis kedua dapat diterima kepuasan kerja berpengaruh positif terhadap komitmen organisasi. Hasil penelitian ini didukung oleh penelitian Alvianto et al (2020) Sampel penelitian karyawan PT Sapta Saritama Yogyakarta menunjukkan bahwa kepuasan kerja berpengaruh positif terhadap komitmen organisasi. Selaras dengan Saragih dan Suhendro (2020) meneliti bapak/ibu guru SMA Negeri I Dolok Batu Nanggar menunjukkan kepuasan kerja guru berpengaruh positif dan signifikan terhadap komitmen guru. Komitmen organisasi dapat tumbuh dari kepuasan kerja yang diterima.

Dengan adanya temuan ini, menandakan bahwa pengembangan karir dan kepuasan kerja yang diterima bapak/ibu guru di sebuah SMA di Jakarta berbanding lurus dengan definisi teori komitmen organisasi dimana karyawan yang memperoleh kesempatan berkarir dan memperoleh kepuasan kerja dapat menambah komitmen mereka terhadap institusi mereka bekerja.

\section{KESIMPULAN}

Dalam suatu penelitian pasti terdapat suatu keterbatasan. Pada penelitian ini, terdiri dari beberapa keterbatasan, yaitu dengan waktu penelitian yang relatif singkat, jumlah responden yang terkumpul terbatas yaitu hanya sebanyak 55 responden, dan variabel-variabel yang digunakan untuk menjelaskan komitmen organisasi pada penelitian ini hanya terbatas pada variabel pengembangan karir dan kepuasan kerja.

Berdasarkan hasil penelitian, menunjukkan pengembangan karir berpengaruh terhadap komitmen organisasi pada guru di sebuah SMA di Jakarta dan kepuasan kerja berpengaruh terhadap komitmen organisasi pada guru di sebuah SMA di Jakarta maka peneliti akan memberikan saran yang bermanfaat bagi peneliti selanjutnya, yaitu untuk Sekolah SMAN 111 Jakarta mempertahankan dimensi informasi promosi pada pengembangan karir karena mayoritas bapak ibu/guru setuju pengembangan karir di sebuah SMA di Jakarta terjadi secara terbuka dan transparan dengan sikap kepala sekolah yang memberikan informasi secara terbuka dan transparan kepada guru untuk mengikuti promosi calon kepala sekolah, meningkatkan dimensi kepedulian atasan pada pengembangan karir karena kepala sekolah belum memberikan pelatihan dan diklat yang dibutuhkan guru dalam meningkatkan kemampuan manajerial yang mereka miliki, mempertahankan dimensi supervision kepuasan kerja karena mayoritas bapak/ibu guru setuju kepemimpinan kepala sekolah telah mampu membangkitkan motivasi kerja guru untuk mencapai target yang telah ditetapkan pada tahun pelajaran untuk peningkatan capaian kriteria nilai minimum siswa, meningkatkan dimensi work it self pada kepuasan kerja karena bapak/ibu guru tidak setuju dengan perasaan senang akan tanggung jawab dalam pekerjaan hal ini dikarenakan belum seimbangnya antara jumlah pekerjaan dengan penghasilan yang diterima sehingga mengakibatkan guru tidak puas dengan tanggung jawab pekerjaan yang diberikan. Sementara untuk peneliti lain bila meneliti variabel yang sama, maka diharapkan untuk menambahkan atau menggantikan variabel independennya dengan variabel lain yang dapat berpengaruh terhadap variabel dependennya. Dan peneliti juga menyarankan untuk menambahkan jumlah responden supaya dapat memberikan hasil yang optimal.

\section{DAFTAR PUSTAKA}

Arikunto, S. (2013). Prosedur penelitian: suatu pendekatan praktik. Jakarta: Rineka Cipta. 
Al-Shawabkeh, K. M. (2017). Career path development and its impact on organizational citizenship behavior in greater amman municipality. International Journal of Business and Management, 12(3), 79-91.

Chandra, D. O. \& Bahri, T. E. (2020). Pengaruh budaya organisasi dan pengembangan karir terhadap komitmen kerja karyawan pada PT. Nusa Raya Cipta. Jurnal Muhammadiyah Manajemen Bisnis, 1(1), 28-32.

Hair, J. F., Hault, G., Ringle, C. \& Sartedt, M. (2014). A primer on partial least squares structural equation modeling (PLS SEM). USA: SAGE.

Hasibuan, M. S. P. (2016). Manajemen sumber daya manusia. Jakarta: Penerbit Bumi Aksara.

Karia, N. \& Assari, M. H. A. H. (2018). Leadership attributes and their impact on work-related attitudes. International Journal of Productivity and Performance Management, 68(5), 903-919.

Mangkunegara, A. A. P. (2013). Manajemen sumber daya manusia perusahaan. Bandung: Remaja Rosdakarya.

Marbun, J. Y. \& Kasmirudin. (2017). Pengaruh pengembangan karir dan komitmen organisasi terhadap kepuasan kerja karyawan (studi karyawan bagian umum PT Perkebunan Nusantara V Pekanbaru). JOM FISIP, 4(2), 1-14.

Priansa, D. J. (2018). Perencanaan \& pengembangan SDM. Bandung: Alfabeta.

Pritanadhira, A. (2019). Karakteristik psikometris skala komitmen organisasi Allen \& Meyer pada pegawai negeri sipil RSUP Dr. Soeradji Tirtonegoro. Indonesian Journal of Islamic Psychology, 1(1), 35-55.

Robbins, S. P. \& Timothy A. J. (2018). Perilaku organisasi Edisi 16. Jakarta: Salemba Empat.

Saragih, I. S. \& Suhendro, D. (2020). Pengaruh iklim organisasi sekolah, budaya kerja guru, dan kepuasan kerja terhadap komitmen kerja guru. Jurnal Akuntabilitas Manajemen Pendidikan, 8(1), 44-52.

Siagian, S. P. (2015). Manajemen sumber daya manusia. Jakarta: Bumi Aksara.

Widodo, S. E.(2016). Manajemen pengembangan sumber daya manusia. Yogyakarta: Pustaka Pelajar.

Yunus, N. M. T., Hamid, N. \& Yusuf, R. M. (2018). Kepemimpinan dan pengembangan karir terhadap komitmen organisasional serta dampaknya pada kinerja karyawan PT. Bank Mandiri Tbk area Makassar Kartini. Journal of Applied Business and Entrepreneurship, $1(2), 50-60$. 